Available online at GSC Online Press Directory

GSC Biological and Pharmaceutical Sciences

e-ISSN: 2581-3250, CODEN (USA): GBPSC2

Journal homepage: https://www.gsconlinepress.com/journals/gscbps

(RESEARCH ARTICLE)

\title{
Antimicrobial, antioxidant and phytochemical investigation of Thuja occidentalis (Arbor vitae) leave extract
}

\author{
Deepika Tekaday ${ }^{1}$, Reena Antony ${ }^{1}$ and Sourabh Jain ${ }^{2 *}$ \\ ${ }^{1}$ Department of Microbiology, Career College, Sector A, Govindpura, Bhopal, MP, 462023. \\ ${ }^{2}$ Pinnacle Biomedical Research Institute, Bharat Scout and Guides Campus, Shanti Marg, Shyamla Hills, Depot Chouraha, \\ Bhopal, MP, 462003.
}

Publication history: Received on 06 September 2020; revised on 12 September 2020; accepted on 15 September 2020

Article DOI: https://doi.org/10.30574/gscbps.2020.12.3.0292

\begin{abstract}
Various medicinal plants are common in use in India for the treatment of different diseases. Nowadays, drug resistance has emerged as a major problem for various infections, in such case plants can be used as alternative for the production of new medicine. Thuja occidentalis (T. occidentalis, Cupressacae) is a well-known medicinal plant. The aim of the present study was to evaluate qualitative and quantitative phytochemical analysis and in vitro antioxidant and antimicrobial activities of leaf of T. occidentalis collected from Bhopal region of Madhya Pradesh. Qualitative analysis of various phytochemical constituents and quantitative analysis of total phenolics and flavonoids were determined by the well-known test protocol available in the literature. Quantitative analysis of phenolic and flavonoids was carried out by Folins Ciocalteau reagent method and aluminium chloride method respectively. The in vitro antioxidant activity of methanolic extract of the leaves was assessed against DPPH and reducing power assay method using standard protocols and in vitro antimicrobial activity was done by well diffusion assay method. Phytochemical analysis revealed the presence of alkaloids, glycosides, phenols, flavonoids, tannins. The total phenolics content of leaves of methanolic extract was $(0.125 \mathrm{mg} / \mathrm{gm})$, followed by flavonoids $(0.475 \mathrm{mg} / \mathrm{gm})$. The activities of all leaves extract against DPPH and reducing power assay method were concentration dependent. The antimicrobial acuity of methanolic extract of leave against all microorganisms was concentration dependent manner but less than standard drug (Ofloxacin, Amphotericin B). The present study concluded that the crude extract of $T$. occidentalis is a rich source of secondary phytoconstituents which impart significant antioxidant and antimicrobial potential. The findings of the present study will be helpful to phytochemists, pharmacologists and pharmaceutical industries.
\end{abstract}

Keywords: Thuja occidentalis; Physicochemical; Qualitative; Quantitative phytochemical; Antioxidant; Antimicrobial.

\section{Introduction}

Various plants have been used as traditional medicine from the ancient time of human civilization. Many ancient documents revealed that plants were used for medicinal purposes in china, India, Egypt and Greece long before the beginning of Christian era. Various plants also contain antioxidants, which help in shielding the cells against the harmful effects of reactive oxygen species. Antioxidants are present in our body in an appropriate quantity but to protect our body from these reactive oxygen species (ROS) there is need of antioxidants from natural so urces [2]. The medicinal plants possess phenolic compounds that possess very strong antioxidant activity and in turn help the body against the damage by free radicals [3]. These phenolic compounds act as radical scavengers, reducing agents, nascent oxygen quenchers, hydrogen donors and metal chelators [4]. An antioxidant is defined as any substance which when present at

\footnotetext{
${ }^{*}$ Corresponding author: Sourabh Jain

Pinnacle Biomedical Research Institute Near, Bharat Scout and Guides Campus, Shanti Marg, Shyamla Hills Road, Depot Chouraha, Bhopal, MP, 462003.
}

Copyright $(2020$ Author(s) retain the copyright of this article. This article is published under the terms of the Creative Commons Attribution Liscense 4.0. 
low concentrations significantly delays or prevents oxidation of an oxidizable substrate by scavenging free radicals [5]. Free radicals and other reactive oxygen species are formed constantly in the human body. They can be useful for some physiological activities but in excess, they may prove very dangerous and harmful for human body. These free radicals generally damage the DNA, carbohydrates, lipids and proteins in body. Free radicals are also produced by environmental pollutants, cigarette smoke, automobile exhaust fumes, radiation, air pollutants and pesticides etc. [6]. There is a balance between the free radicals in body and the antioxidants to scavenge these radicals to protect against their harmful effect. However any increase in free radicals inside the body can produce harmful effects and stress in human body. Thus antioxidants are useful for maintaining the required quantity of free radicals inside the body and scavenge the extra free radicals so that no deleterious effects of these free radicals are found in human body. Plants also used as antimicrobials before microbiological study had even been started [7]. Plant derived bioactive substances are considered a very good and cheap source of medicines that play a significant role for human health improvement as well as used against different types of microbial disease [8,9]. Plants have great medicinal relevance because infections caused by drug resistant microorganisms have become a major therapeutic problem nowadays [10]. In addition, plant extract and their phytochemicals are getting more importance as they have the great potential sources for microbial and viral inhibitors. Therefore, thousands of researchers have focused their interest to investigate phytochemical constituents of plant for human health [11]. The bioactive constituents of plants such as tannins, flavonoids, saponins, terpenoids and alkaloids have great antimicrobial activity [12]. T. occidentalis, commonly known as Arbor vitae or white cedar, is indigenous to eastern North America and is grown in Europe as an ornamental tree [13]. The plant was first identified as a remedy by native Indians in Canada during a 16th century expedition and was found to prove effective in the treatment of weakness from scurvy [14]. In folk medicine, T. occidentalis has been used to treat bronchial catarrh, enuresis, cystitis, psoriasis, uterine carcinomas, amenorrhea and rheumatism [15-18]. Today, it is mainly used in homeopathy as mother tincture or dilution $[19,20]$. In combination with other immunomodulating plants, such as Echinacea purpurea, Echinacea pallida and Baptisia tinctoria, this medicinal plant is also used as evidence-based phytotherapy for acute and chronic infections of the upper respiratory tract [21, 22], and as an adjuvant to antibiotics in severe bacterial infections such as bronchitis, angina, pharyngitis, otitis media and sinusitis [23,24] .Therefore this study was conducted with the aim to investigate phytoconstituents present in leaves of T. occidentalis and assessment of their antioxidant and antimicrobial characteristics.

\section{Material and methods}

\subsection{Plant material}

The leaves of T. occidentalis were collected from local area of Bhopal (M.P.) in the month of February, 2018.The sample was identified by senior Botanist Dr. Zia-Ul-Hassan, Professor and head of department of Botany, Safia College of Arts and Science, peer gate Bhopal. A herbarium of plants was submitted to the specimen library of Safia College of Arts and Science, peer gate Bhopal and The specimen voucher no. of T. occidentalis is 119/Bot/Saf/45.

\subsection{Chemical reagents}

All the chemicals used in this study were obtained from HiMedia Laboratories Pvt. Ltd. (Mumbai, India), Sigma Aldrich Chemical Co. (Milwaukee, WI, USA), SD Fine-Chem. Ltd. (Mumbai, India) and SRL Pvt. Ltd. (Mumbai, India). All the chemicals used in this study were of analytical grade.

\subsection{Bacterial strain}

The test organisms Pseudomonas auregenosa (MTCC 2075), Bacillus subtilis (MTCC 1133), Salmonella (MTCC 1169), Bacillus cereus (MTCC 1305), Aspergillus niger (MTCC 872), Candida krusie (MTCC 9215) were obtained from the stocks of the Pinnacle Biomedical Research Institute, Bharat Scout \& Guides Campus, Shyamla Hills, Bhopal, (M.P.).

\subsection{Maintenance of bacterial culture}

The Bacterial strains were grown on nutrient agar media and inoculate at $37^{\circ} \mathrm{C}$ temperature for 24 hours and fungal strains were grown on SDA medium. Then organisms were maintained on nutrient agar slant at $4^{\circ} \mathrm{C}$ temperature and the purity of the organisms was checked at regular intervals by plating.

\subsection{Extraction of plant material}

Leaves of T. occidentalis were collected, washed and rinsed properly. They were dried in shade and powdered mechanically. About 500gm of the leaves powder was macerated with methanol and stored for 72 hours in ice cold condition for the extraction of phytochemicals. At the end of the third day extract was filtered using whatman No. 1 filter paper to remove all un-extractable matter, including cellular materials and other constitutions that are insoluble in the 
extraction solvent. The entire extract was concentrated to dryness using rotary flash evaporator under reduced pressure and stored in an air tight container free from any contamination until it was used. Finally the percentage yields were calculated of the dried extracts [25].

\subsection{Qualitative phytochemical analysis of plant extract}

The T. occidentalis leaves extract obtained was subjected to the preliminary phytochemical analysis following standard methods $[26,27]$. The extract was screened to identify the presence or absence of various active principles like phenolic compounds, carbohydrates, flavonoids, glycosides, saponins, alkaloids, fats or fixed oils, protein and amino acid and tannins.

\subsection{Quantification of secondary metabolites}

Quantitative analysis is an important tool for the determination of quantity of phytoconstituents present in plant extracts. For this TPC and TFC are determined. Extracts obtained from leaves of T. occidentalis plant material of subjected to estimate the presence of TPC and TFC by standard procedure.

\subsubsection{Total phenolic content estimation}

The amount of total phenolic in extracts was determined with the folin ciocalteu reagent. Concentration of $(20-100$ $\mu \mathrm{g} / \mathrm{ml}$ ) of gallic acid was prepared in methanol. Concentration of $100 \mu \mathrm{g} / \mathrm{ml}$ of plant extract were also prepared in methanol and $0.5 \mathrm{ml}$ of each sample were introduced in to test and mixed with $2 \mathrm{ml}$ of a 10 fold dilute folin Ciocalteu reagent and $4 \mathrm{ml}$ of $7.5 \%$ sodium carbonate. The tubes were covered with parafilm and it was then Incubated at room temperature for 30 mins with intermittent shaking and the absorbance were taken at $765 \mathrm{~nm}$ against using methanol as blank. Total phenolic content was calculated by the standard regression curve of Gallic acid and the results were expressed as gallic acid equivalent $(\mathrm{mg} / \mathrm{g})$ [28].

\subsubsection{Total flavonoid content estimation}

Different concentration of rutin $(20$ to $100 \mu \mathrm{g} / \mathrm{ml}$ ) was prepared in methanol. Test sample of near about same polarity $(100 \mu \mathrm{g} / \mathrm{ml})$ were prepared. An aliquot $0.5 \mathrm{ml}$ of diluted sample was mixed with $2 \mathrm{ml}$ of distilled water and subsequently with $0.15 \mathrm{ml}$ of a $5 \% \mathrm{NaNO}_{2}$ solution. After $6 \mathrm{~min}, 0.15 \mathrm{ml}$ of a $10 \% \mathrm{AlCl}_{3}$ solution was added and allowed to stand for $5 \mathrm{~min}$, and then $2 \mathrm{ml}$ of $4 \% \mathrm{NaOH}$ solution was added to the mixture. The final volume was adjusted to $5 \mathrm{ml}$ with distilled water and allowed to stand for another 15 mins. Absorbance was determined at $510 \mathrm{~nm}$ against water as blank. Total flavonoid content was calculated by the Standard regression curve of Rutin/ Quercetin [29].

\subsection{Antioxidant activity}

\subsubsection{DPPH radical scavenging activity}

For DPPH assay, the method of Gulçin et al., 2006 [30] was adopted. A solution of 0.1mM DPPH (4mg/100ml) in methanol was prepared and $1 \mathrm{ml}$ of this solution was mixed with $1 \mathrm{ml}$ of different concentrations of the different extracts. The reaction mixture was vortexed thoroughly and left in the dark at room temperature for 30 min. Ascorbic acid was used as reference standard while methanol was used as control. Reduction of the stable DPPH radical was used as a marker of antioxidant capacity of T. occidentalis extracts. The change in colour was measured at $517 \mathrm{~nm}$ wavelength using methanolic solution as a reference solution. This was related to the absorbance of the control without the plant extracts. The percentage inhibition of free radical DPPH was calculated from the following equation: \% inhibition = [(absorbance of control - absorbance of sample)/absorbance of control] $\times 100 \%$. All the tests were carried out in triplicates. Though the activity is expressed as 50\% inhibitory concentration (IC50), IC50 was calculated based on the percentage of DPPH radicals scavenged. The lower the IC50 value, the higher is the antioxidant activity.

\subsubsection{Reducing power assay}

A spectrophotometric method was used for the measurement of reducing power. For this $0.5 \mathrm{ml}$ of each of the extracts was mixed with $0.5 \mathrm{ml}$ phosphate buffer $(0.2 \mathrm{M}, \mathrm{pH} 6.6)$ and $0.5 \mathrm{ml}$ of $1 \%$ potassium ferricyanide $(10 \mathrm{mg} / \mathrm{ml})$. The reaction mixture was incubated at $50^{\circ} \mathrm{C}$ for 20 min separately, and then rapidly cooled, mixed with $1.5 \mathrm{ml}$ of $10 \%$ trichloroacetic acid and centrifuged at $6500 \mathrm{rpm}$ for $10 \mathrm{~min}$. An aliquot $(0.5 \mathrm{ml})$ of the supernatant was diluted with distilled water $(0.5 \mathrm{ml})$ and then ferric chloride $(0.5 \mathrm{ml}, 0.1 \%)$ was added and allowed to stand for 10 min. the absorbance was read spectrophotometrically at $700 \mathrm{~nm}$. Ascorbic acid (AA) was used as standard for construction of calibration curve [31].

Reducing Power $(\%)=($ As $/$ Ac $) \times 100$ 
Here, Ac is the absorbance of control (AA) and as is the absorbance of samples (extracts) or standards.

\subsection{In vitro antimicrobial activity}

\subsubsection{Well diffusion method}

The agar well diffusion method technique Bauer et al., 1966 [32] was used to determine the antibacterial activity of the plant extracts. Inoculation was done on sterile nutrient agar media plate. A sterile $5 \mathrm{~mm}$ cork borer was used to punch holes after solidification of media. The wells formed were filled with different concentrations of the extract which were labeled accordingly; $100 \mathrm{mg} / \mathrm{ml}, 150 \mathrm{mg} / \mathrm{ml}, 200 \mathrm{mg} / \mathrm{ml}, 250 \mathrm{mg} / \mathrm{ml}$. The plates were then left on the bench for 1 hour for adequate diffusion of the extracts and incubated at $37^{\circ} \mathrm{C}$ for 48 hours in upright condition. The Experiment was repeated triplets and the mean values were calculated.

\subsubsection{Interpretation of well diffusion assay}

After incubation, the diameter of the zones of inhibition around each well were measured to the nearest millimeters along two axis i.e. $90^{\circ}$ to each other and the mean of the four reading were then calculated included $5 \mathrm{~mm}$ well.

\section{Results and discussion}

The crude extracts so obtained after each of the successive cold maceration extraction process were concentrated on water bath by evaporation the solvents completely to obtain the actual yield of extraction. The percentage yield of extraction is very important in phytochemical extraction in order to evaluate the standard extraction efficiency for a particular plant, different parts of same plant or different solvents used. The yield of extracts obtained from the leaves of the plants using methanol as solvents are depicted in the Table 1 . The results of qualitative phytochemical analysis of the crude powder of leaves of T. occidentalis are shown in Table 2. Methanolic extracts of leaves sample of T. occidentalis showed the presence of carbohydrates, alkaloids, flavonoids, phenols, tannins and glycosides. Quantitative phytochemical assay was performed by calculating total phenolic content (TPC) and total flavonoid content (TFC). The TPC was calculated with respect to gallic acid (standard) and TFC was then calculated with respect to rutin taken as standard. The TPC and TFC in methanolic extract were found to be $0.125 \mathrm{mg} / \mathrm{gm}$ and $0.475 \mathrm{mg} / \mathrm{gm}$ respectively Table 3\& Figure 1, 2. Antioxidant activity of the samples was calculated through DPPH assay and reducing power assay. \% inhibition was calculated as an indicative of antioxidant potency. The higher the \% inhibition the better the activity. Ascorbic acid was taken as standard in both the tests and the values were comparable with concentration ranging from $20 \mu \mathrm{g} / \mathrm{ml}$ to $100 \mu \mathrm{g} / \mathrm{ml}$. A dose dependent activity with respect to concentration was observed. \% inhibition was higher in the ascorbic acid while the values were lesser in methanolic extract Table 4. The reducing ability of the compound usually depends on the reductants, which have been exhibited antioxidative capacity by breaking the free radical chain, donating a hydrogen atom. Reducing power assay was calculated in extracts and the values indicated a better activity Table 5.In-vitro antimicrobial activity was also calculated in order to estimate the antimicrobial activity of the extracts. The method chosen to analyse the antimicrobial activity was well diffusion assay. Methanolic extract was tested for its antimicrobial activity on the organism's B. cereus, Pseudomonas, Salmonella, B. subtilis, A. niger, C. albcans. Varying concentrations of the extract was administered to the organisms consisting of 100, 150, $200 \mathrm{and} 250 \mathrm{mg} / \mathrm{ml}$. The zone of inhibition of all treated microorganisms was calculated. The values of zone of inhibition obtained were dose dependent, that is, the higher the dose the larger the zone of inhibition Table 6 \& 7.

Table 1 Results of percentage yield of leaves extracts

\begin{tabular}{|l|l|}
\hline Plant Name & Percentage yield (\%) \\
\hline & Methanol \\
\hline T. occidentalis & 6.35 \\
\hline
\end{tabular}


Table 2 Phytochemical evaluation of $B$. lanzanleaves

\begin{tabular}{|c|c|}
\hline Test & Methanolic extract \\
\hline \multicolumn{2}{|l|}{ Carbohydrates } \\
\hline Molish & $+\mathrm{Ve}$ \\
\hline Fehling's & $-\mathrm{Ve}$ \\
\hline Benedict's & $-\mathrm{Ve}$ \\
\hline \multicolumn{2}{|c|}{ Test for protein and amino acid } \\
\hline Biuret & $-\mathrm{Ve}$ \\
\hline Ninhydrin & $-\mathrm{Ve}$ \\
\hline \multicolumn{2}{|l|}{ Test for glycosides } \\
\hline Borntrager's & $-\mathrm{Ve}$ \\
\hline Keller-killani & $-\mathrm{Ve}$ \\
\hline \multicolumn{2}{|l|}{ Test for alkaloids } \\
\hline Mayer's & $-\mathrm{Ve}$ \\
\hline Hager's & $+\mathrm{Ve}$ \\
\hline Wagner's & $+\mathrm{Ve}$ \\
\hline \multicolumn{2}{|l|}{ Test for saponins } \\
\hline Froth Test & $+\mathrm{Ve}$ \\
\hline \multicolumn{2}{|l|}{ Test for flavonoids } \\
\hline Lead acetate & $+\mathrm{Ve}$ \\
\hline Alkaline reagent & $+\mathrm{Ve}$ \\
\hline \multicolumn{2}{|c|}{ Test for triterpenoids and steroids } \\
\hline Salkowski’s & $+\mathrm{Ve}$ \\
\hline Libermann-burchard's & $+\mathrm{Ve}$ \\
\hline \multicolumn{2}{|c|}{ Test for Tannin and phenolic compounds } \\
\hline Ferric chloride & $-\mathrm{Ve}$ \\
\hline Lead acetate & $+\mathrm{Ve}$ \\
\hline Gelatin & $+\mathrm{Ve}$ \\
\hline
\end{tabular}

(+) Indicates Presence; (-) Indicates Absence

Table 3 Total phenolic and flavonoid content of extracts

\begin{tabular}{|l|l|}
\hline Test & Methanolic extract \\
\hline TPC & $0.125 \mathrm{mg} /$ gm equivalent to Gallic acid \\
\hline TFC & $0.475 \mathrm{mg} /$ gm equivalent to Rutin \\
\hline
\end{tabular}




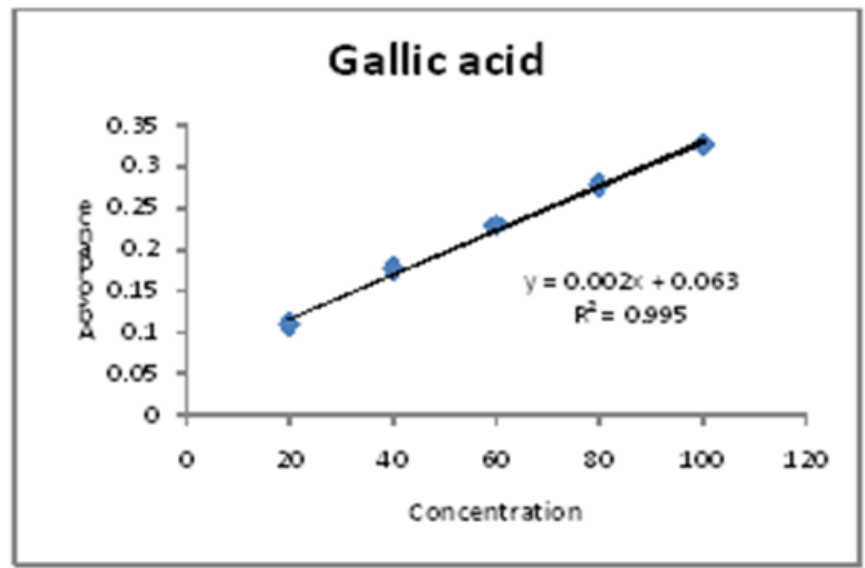

Figure 1 Graph of estimation of total phenolic content

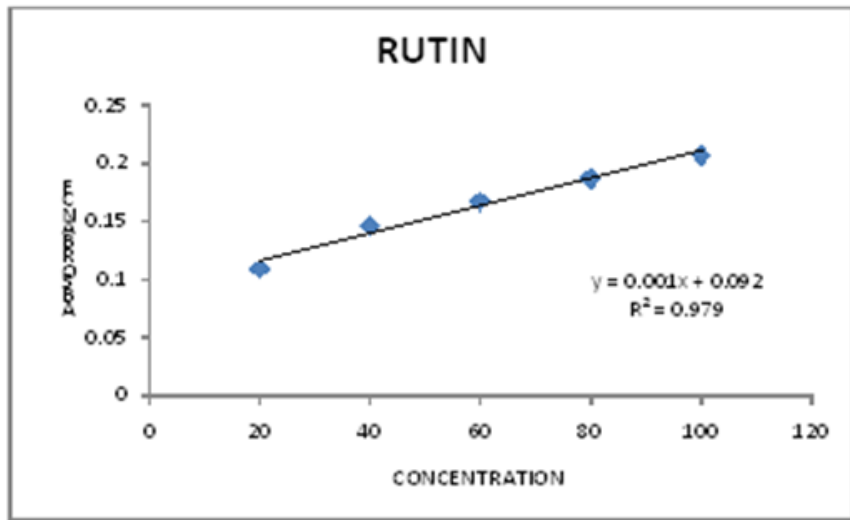

Figure 2 Graph of estimation of total flavonoids content

Table 4 DPPH assay of ascorbic acid and methanolic extract

\begin{tabular}{|l|l|l|l|}
\hline S. No. & Conc. $(\boldsymbol{\mu g} / \mathbf{m l})$ & $\begin{array}{l}\text { Ascorbic acid } \\
\text { (\% Inhibition) }\end{array}$ & $\begin{array}{l}\text { Methanolic Extract } \\
\text { (\% Inhibition) }\end{array}$ \\
\hline 1. & 20 & 47.28 & 38.37 \\
\hline 2. & 40 & 54.17 & 45.06 \\
\hline 3. & 60 & 60.69 & 48.68 \\
\hline 4. & 80 & 68.84 & 55.81 \\
\hline 5. & 100 & 73.91 & 59.32 \\
\hline \multicolumn{2}{|l}{ IC 50 Value } & 25.07 & 62.129 \\
\hline
\end{tabular}

Table 5 Result of reducing power assay

\begin{tabular}{|l|l|l|}
\hline S. No. & Ascorbic acid & Methanolic Extract \\
\hline 1. & 0.987 & 0.054 \\
\hline 2. & 1.032 & 0.14 \\
\hline 3. & 1.145 & 0.174 \\
\hline 4. & 1.159 & 0.188 \\
\hline 5. & 1.196 & 0.246 \\
\hline
\end{tabular}


Table 6 Antimicrobial activity of methanolic extract

\begin{tabular}{|l|l|l|l|l|}
\hline \multicolumn{2}{|l}{ Extract } & \multicolumn{5}{l|}{} \\
\hline Organisms & $100 \mathrm{mg} / \mathrm{ml}$ & $150 \mathrm{mg} / \mathrm{ml}$ & $200 \mathrm{mg} / \mathrm{ml}$ & $250 \mathrm{mg} / \mathrm{ml}$ \\
\hline P. auregenosa & $7.75 \pm 0.500$ & $9.00 \pm 0.816$ & $10.00 \pm 0.000$ & $12.00 \pm 0.816$ \\
\hline B. subtilis & $7.75 \pm 0.957$ & $9.75 \pm 0.957$ & $11.25 \pm 0.500$ & $13.75 \pm 0.500$ \\
\hline Salmonella & $5.50 \pm 0.577$ & $7.75 \pm 0.957$ & $9.50 \pm 0.577$ & $12.00 \pm 0.816$ \\
\hline B. cereus & $6.50 \pm 0.577$ & $8.75 \pm 0.500$ & $10.50 \pm 0.577$ & $12.00 \pm 0.816$ \\
\hline A. niger & $8.50 \pm 0.577$ & $10.25 \pm 0.500$ & $11.75 \pm 75 \pm 0.500$ & $13.50 \pm 0.577$ \\
\hline C. krusie & $8.50 \pm 0.577$ & $10.75 \pm 0.500$ & $11.75 \pm 0.500$ & $12.50 \pm 0.577$ \\
\hline
\end{tabular}

Table 7 Antimicrobial activity of Standard drugs

\begin{tabular}{|l|l|l|l|l|l|}
\hline \multicolumn{2}{|l|}{ Standard } & \multicolumn{2}{l|}{ Amphotericin B } \\
\hline Ofloxacin & B. subtilis & Salmonella & B. cereus & A. niger & C. krusie \\
\hline P. auregenosa & $28.50 \pm 0.577$ & $29.50 \pm 0.577$ & $28.75 \pm 0.500$ & $29.25 \pm 0.957$ & $31.00 \pm 0.816$ \\
\hline $29.25 \pm 0.500$ & &
\end{tabular}

\section{Conclusion}

T. occidentalis exhibited the potential antibacterial and antioxidant activities. The leaf extracts of this plant have various phytochemicals such as alkaloids, glycosides, flavonoids, steroids, tannins, terpenoids and saponins. Which are responsible for these activities? The methanolic extract has good antimicrobial activity against the tested microorganism. The plant exhibited the admirable antioxidant activity in methanol extracts. The observed good antioxidant activity of the extract indicates the potential of the leaves as a source of natural antioxidant.

\section{Compliance with ethical standards}

\section{Acknowledgments}

The authors are very grateful to Dr. Megha Jha, Manager and Head, Department of Research and Dr. Azaz Khan Director, Pinnacle Biomedical Research Institute, Bhopal (M.P), for providing experimental facilities, and for her appropriate and constructive suggestions for the present study.

\section{Disclosure of conflict of interest}

The authors declare no conflict of interest, financial or otherwise.

\section{References}

[1] Agbor G, Oben J, Ngogang J, Xinxing C, Vinson J. Antioxidant capacity of some herbs/spices from cameroon: a comparative study of two methods. Journal of Agricultural and Food Chemistry. 2005; 53(17): 6819-24.

[2] Brewer MS. Natural antioxidants: sources, compounds, mechanisms of action, and potential applications. Comprehensive Reviews in Food Science and Food Safety. 2011; 10(4): 221-47.

[3] Kahkonen M Hopia A, Vuorela H, Rauha J, Pihlaja K, Kujala T, et al. Antioxidant activity of plant extracts containing phenolic compounds. Journal of Agricultural and Food Chemistry. 1999; 47(10): 3954-62.

[4] Proestos C, Boziaris I, Nychas G, Komaitis M. Analysis of flavonoids and phenolic acids in Greek aromatic plants: Investigation of their antioxidant capacity and antimicrobial activity. Food Chemistry. 2006; 95(4): 664-71.

[5] Halliwell B, Gutteridge MC. Free radicals in biology and medicine. The International Journal of Biochemistry \& Cell Biology. 1999; 31(12): 1454. 
[6] Sies H. Oxidative stress: from basic research to clinical application. The American Journal of Medicine. 1991; 91(3): 31-8.

[7] Gyawali R. History of Pharmacognosy. Handbook of Pharmaognosy. 1st ed. Bagbazar, Kathmandu, Nepal: Nabodit Hamro Pustak Bhandar, 2013.

[8] Kumar PV, Chauhan SN, Padh H, Rajani M. Search for antibacterial and antifungal agents from selected Indian medicinal plants. Journal of Ethnopharmacology. 2006;107:182-188.

[9] Mathabe MC, Nikolova RV, Laly N, Nyazema NZ. Antibacterial activities of medicinal plants used for the treatment of diarrhoea in Limpopo Province, South Africa. Journal of Ethnopharmacology.2006; 107: 286-293.

[10] Valgas C, Souza, SMD, Smânia EFA, Artur Smânia Jr. Screening methods to determine antibacterial activity of natural products. Brazilian Journal of Microbiology. 2007; 38(2): 369-380.

[11] Jasuja ND, Saxena R, Chandra S, Sharma R. Pharmacological characterization and beneficial uses of Punicagranatum. Asain Journal of Plant Sciences. 2012; 11:251-267.

[12] Sah SN, Regmi S, Tamang MK. Antibacterial effects of thuja leaves extract. International Journal of Applied Sciences and Biotechnology. 2017; 5(2): 256-260.

[13] Chang LC, Song LL, Park EJ, et al. Bioactive constituents of Thuja occidentalis. Journal of Natural Products. 2000; 63:1235-8.

[14] Millspaugh CF. American Medicinal Plants. Thuja. Dover Publications, New York, 1974.

[15] British Herbal Pharmacopoeia. Thuja. British Herbal Medicine Association, West Yorks, UK, 1983; 210-1.

[16] Shimada K. Contribution to anatomy of the central nervous system of the Japanese upon the vermal arbour vitae. Okajimas Folia Anatomica Japonica. 1956; 28:207-27.

[17] Baran D. Arbor vitae, a guarantee of health. Revista medico-chirurgicala a Societatii de Medici si Naturalisti din Iasi. 1991; 95:347-9.

[18] Offergeld R, Reinecker C, Gunz E, et al. Mitogenic activity of high molecular polysaccharide fractions isolates the cuppressaceae Thuja occidentalis L. enhanced cytokine-production thyapolysaccharide, g-fraction (TPSg). Leukemia. 1992; 6:189-91.

[19] Homoopathisches Arzneibuch (HAB). Thuja Monograph. Deutscher Apotheker Verlag Stuttgart. 1985; 876-7.

[20] Homoopathisches Arzneibuch (HAB). Thuja Monograph. Deutscher Apotheker Verlag Stuttgart. 2003; 1-2.

[21] Reitz HD, Hergarten H. Immunmodulatoren mit pflanzlichen Wirkstoffen-2. Teil: eine wissenschaftliche Studie am Beispiel Esberitox® N. Notabene Medici. 1990;20:304-6.

[22] Vorberg G. Bei Erkaltung unspezifische Immunabwehr stimulieren. Arztl Prax 1984; 36:97-8.

[23] Von Blumroder WO. Angina lacunaris. Z Allgemeinmed. 1985; 61:271-3.

[24] Zimmer M. Gezielte konservative Therapie der akuten Sinusitis in der HNO-Praxis. Therapiewoche. 1985; 35:4024-8.

[25] Nayak A, Garg M, Jain S, Khan MA, Jain DK, Khan N. Anti-Urolithiatic and invitro-invivo anti-oxidant effects of methanolic extract of thunbergia laurifolia on ethylene glycol-induced kidney calculi in rats. Scholars Academic Journal of Pharmacy. 2019; 8(3): 94-104.

[26] Jain DK, Nayak A, Patel P, Jain A, Khan MA. Appraisal of in vitro antioxidant and in vivo anti-inflammatory activities of various extracts from the fruits of vitis vinifera L. Scholars Academic Journal of Pharmacy. 2019; 8 (3): 86-93.

[27] Jain DK, Patel NS, Nagar H, Patel A, Chandel HS. Anti-arthritic activity of tridax procumbens ethanolic extract of leaves. RGUHS Journal of Pharmaceutical Sciences. 2012; 2(4): 80-86.

[28] Ainsworth EA, Gillespie KM. Estimation of total phenolic content and other oxidation substrates in plant tissue using Folin-Ciocalteu reagent. Nature Protocol. 2007; 2(4): 875-877.

[29] Zhishen J, Mengcheng T, Jianming W. The determination of flavonoid contents in mulberry and their scavenging effects on superoxide radicals. Food Chemistry. 1999; 64: 555-559.

[30] Gulçin I, Elias R, Gepdiremen A, Boyer L. Antioxidant activity of lignans from fringe tree (Chionanthus virginicus L.). European Food Research and Technology. 2006; 223: 759-767. 
[31] Jain R, Jain SK. Total Phenolic Contents and Antioxidant Activities of Some Selected Anticancer Medicinal Plants from Chhattisgarh State, India. Pharmacologyonline. 2011; 2: 755-762.

[32] Bauer AW, Kirby WM, Sherris JC, Turck M. Antibiotic susceptibility testing by a standardized single disk method. American journal of clinical pathology. 1966; 45(4):493.

\section{Author's short biography}

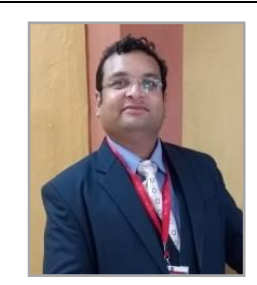

\section{Dr. Sourabh Jain}

Author has completed his UG (2003) \& PG (2008) in Pharmacy from VNS Institute of Pharmacy, Bhopal (MP) \& PhD (Pharmaceutics) from Banasthali Vidyapith, Banasthali (Rajasthan). Also qualified GATE 2006 and completed HDCA (diploma) from AISECT. Author is having academic experience of 08 years and research experience of 06 years. He has published 36+ research and review articles in international and national journals. He was worked as Preclinical Scientist in Pinnacle Biomedical Research Institute (PBRI), Bhopal (MP) from 2012 to 2018 and presently worked as Professor in Dr APJ Abdul Kalam University, Indore (MP) since 2018 and area of interest is preclinical research, and NDDS formulation development. Serving as Joint Secretary in Indian Pharmaceutical Graduates' Association (IPGA) M.P. State Branch. Active reviewer and editorial member of various journals. 